\title{
Enlightenment philosophy and scepticism
}

\begin{abstract}
The article discusses the role of scepticism in the Enlightenment. For many historians of philosophy, Enlightenment was a hiatus in the history of scepticism. Ideas often attributed to the Enlightenment, such as the cult of reason, optimism and the belief in progress, seem to be contrary to scepticism. I argue that this simplistic view of the Enlightenment is far from reality. The Enlightenment not only brought forth such great followers of scepticism as Hume, but also influenced other thinkers in many different ways. The influence of scepticism is not always clearly visible in the philosophical works of that time. Moreover, few philosophers would describe themselves as sceptics. Nevertheless, if one considers different ways in which scepticism influenced Enlightenment philosophy, it becomes apparent that the assertion that scepticism was allegedly absent in the Enlightenment is untenable.
\end{abstract}

Keywords: scepticism, Enlightenment, Hume, Popkin

$\mathrm{M}$ odern scepticism is a very diverse phenomenon. While the common characteristic of different kinds of scepticism is their reference to the teachings of ancient sceptics, especially the teachings of Sextus Empiricus, modern scepticism has evolved through a variety of approaches and currents blending with cultural and philosophical background of the new times. ${ }^{1}$ As a result, modern scepticism never occurs in a pure form, but it is always connected with many elements of the cultural background in which it develops and constitutes specific intellectual constellations.

${ }^{1}$ G. Paganini, Introduction, in G. Paganini (ed.), The Return of Skepticism, Kluwer Academic, Dordrecht 2003, pp. xi-xii. 
It would be more fitting to speak of many scepticisms than one scepticism. The diversity of modern scepticism results not only from different adaptations of ancient scepticism. Undoubtedly, ancient scepticism was also a diverse intellectual current. Generally speaking, scepticism assumed many different forms across times and places. It "has been many things in its long history: a puzzle, a paradox, a challenge, an argument, an attitude, a way of life.”2 The importance of scepticism in philosophy has not been limited to its role as a particular mode of thinking and a set of assertions about the possibility of attaining knowledge. It has also played a role of an adversary that had to be overcome first in order to build a system of knowledge. For many great philosophers, struggling with scepticism and trying to overcome it was the starting point for philosophical inquiry.

Enlightenment philosophy has often been characterized as a philosophy pervaded with optimism regarding capacities of human reason. Such an optimistic attitude might be seen as conflicting with philosophical scepticism. And indeed, historians of scepticism observe that Enlightenment largely breaks away from scepticism. This view was supported, for instance, by Richard Popkin, who argued that

if the subject is limited to the traditional philosophical meaning of the term, there was, perhaps surprisingly, very little scepticism in the Enlightenment, and what there was represented either a carry-over of the earlier Montaignian or Baylean tradition, or an anticipation of an irrationalist fideistic scepticism that was to flourish with Kierkegaard, or an anticipation of an epistemological scepticism that was to flourish among the early critics of Kant. And, what scepticism there was in the Enlightenment seems to have been located mainly within the person of one man - David Hume. ${ }^{3}$

Very few philosophers of the Enlightenment could call themselves sceptics and be considered sceptics by others. Certainly, it does not mean that scepticism as a subject of philosophical reflection disappeared in the eighteenth century. Enlightenment is full of suspicions and accusations of scepticism. The accusations can be found in religious literature because for many Christian authors scepticism was a potentially dangerous adversary. Philosophers and theologians who criticized sceptical fideism advocated by Pierre Bayle were particularly involved in the battle against scepticism. Also, works of classical sceptics, Sextus Empiricus in particular, were translated and published at that time.

According to Popkin, scepticism was a kind of undercurrent throughout the Enlightenment period. It was marginalized by the intellectual mainstream which rested on the belief in the possibilities of human reason. The presence of scepticism was limited to a few philosophers, including Bayle and Huet at the beginning of the century, David Hume, and the critics of Immanuel Kant. More importantly,

${ }^{2}$ B. Reed, D.E. Machuca, General Introduction, in: B. Reed, D.E. Machuca, Skepticism: From Antiquity to the Present, Bloomsbury, London 2018, p. xiv.

${ }^{3}$ R.H. Popkin, Scepticism in the Enlightenment, in R.H. Popkin et al. (eds), Scepticism in the Enlightenment, Kluwer Academic, Dordrecht 1997, p. 1. 
Popkin claims that scepticism had a very limited influence on the philosophers of the Enlightenment and the philosophical debates of that time. While scepticism in early eighteenth-century philosophy was only a short-lived continuation of the earlier Montaignian scepticism, Hume's sceptical philosophy was utterly dismissed by most thinkers of his time. The works of Popkin, an acknowledged expert in the field, influenced later studies concerned with the history of scepticism. His thesis that Enlightenment was in principle a hiatus in the history of scepticism has been elaborated in more recent studies in that respect. ${ }^{4}$ This understanding of eighteenth-century scepticism dovetails with the widespread notion of the Enlightenment as the age of reason, optimism and the belief in moral and scientific progress. It seems that this simplified picture of the Enlightenment contributed to the dismissal of those aspects of Enlightenment thought which emphasized the limits of human reason and unbelief in human progress.

The picture of Enlightenment scepticism presented by Popkin in his works on the history of scepticism appears inconsistent. On the one hand, Popkin refers to several outstanding philosophers, such as Bayle, Huet and Hume, who not only belonged to the sceptical tradition but also considerably influenced philosophical discourse of their time. In this context, it should be remembered that even if Hume's epistemological scepticism was largely ignored by French philosophes, it influenced Kant's epistemology in a significant way. On the other hand, Popkin jumps to the conclusion that "the Enlightenment was pretty much a hiatus in the continuous development of scepticism." ${ }^{\circ 5}$ The conclusion is not only at variance with what he himself wrote about the philosophy of the eighteenth century but also with what we know today about the presence of sceptical themes in many philosophical works of the age. Although the number of self-declared sceptics was indeed low in the eighteenth century, there were many authors explicitly interested in scepticism and many clandestine philosophical works steeped in scepticism. ${ }^{6}$ There were also philosophical responses to scepticism and refutations of scepticism. Popkin's influential opinion on the general absence of scepticism in the Enlightenment was articulated during a conference in 1963. Several decades later, Popkin changed his view under the influence of arguments from the study of the Enlightenment. In an article published in 1997, he admitted that "scepticism was not petering out in the latter half of the 18th century. It was taking on different forms, and reacting to different ways in which dogmatic philosophers tried to answer the sceptical challenge. Some of its more popular effects involved undermining confidence in the old orders of church and state in Western Europe, breeding a sceptical 'basis'

${ }^{4}$ S. Charles, P.J. Smith, Preface, in S. Charles, P.J. Smith (eds), Scepticism in the Eighteenth Century: Enlightenment, Lumières, Aufklärung, Springer, Dordrecht 2013, p. vi.

${ }^{5}$ R.H. Popkin et al. (eds), Scepticism in the Enlightenment, p. 13.

${ }^{6}$ S. Charles, Introduction: What is Enlightenment Scepticism? A Critical Rereading of Richard Popkin, in S. Charles, P.J. Smith (eds), Scepticism in the Eighteenth Century..., p. 3. 
for democratic and tolerant worlds if no traditional system of ideas or institutions could be rationally defended."

Recent studies in the history of Enlightenment philosophy provide quite a complex picture of the epoch. ${ }^{8}$ The Enlightenment was not only richly diverse in terms of national specificities and intellectual traditions, but also involved internal tensions and contradictions. Given its diversity and incongruities, the intellectual landscape of the period cannot be reduced to simple formulas such as optimism, progress and that belief in reason. Regardless of the fact that these ideas did set the tone for the age of the Enlightenment, each should be understood in a more nuanced fashion. Take the case of reason, for instance. The idea of reason was undoubtedly an important concept of Enlightenment philosophy, but the cult of reason is only a part of the story. As Giorgio Tonelli points out, "the Enlightenment was indeed the Age of Reason but one of the main tasks assigned to reason in that age was to set its own boundaries, carefully establishing the field of possible human knowledge versus things considered above the limits of human understanding." Setting the boundaries of human reason is not the same as scepticism towards reason, but the consequence of both is similar at least in that they dispute the cult of reason. Tonelli questions the simplistic understanding of the Enlightenment as the triumph of reason and the rejection of tradition and authority. Other historians of philosophy noted that traces of scepticism can be found in such philosophers of the Enlightenment as Rousseau and Condorcet. ${ }^{10}$

Sébastien Charles claims that the scepticism of the Enlightenment differs from the scepticism of the Classical period. Perhaps this was the reason why it was not easily discernible in the works of eighteenth-century philosophers. It must be remembered that scepticism took on different forms in different times. It was always connected with a specific philosophical and cultural context. Moreover, it played different roles depending on the goals set by philosophers. It seems that many philosophers of the Enlightenment appreciated the methodological significance of scepticism. They did not accept the radical view of certain ancient sceptics and, like Hume, were looking for a more mitigated form of doubt. And even if the moderate scepticism of the Enlightenment far departed from its ancient predecessor, it "became a prerequisite to the search for truth and a necessary reminder of the true limitations of human understanding [...]. Thus, the use that the Enlightenment made of scepticism was above all pragmatic."11

${ }^{7}$ R. Popkin, New Views on the Role of Scepticism in the Enlightenment, in R.H. Popkin et al. (eds), Scepticism in the Enlightenment, p. 168.

${ }^{8}$ Z. Drozdowicz, Faces of the Enlightenment, Peter Lang, Berlin 2020.

${ }^{9}$ G. Tonelli, The "Weakness" of Reason in the Age of Enlightenment, in R.H. Popkin et al. (eds), Scepticism in the Enlightenment, p. 35.

${ }^{10}$ K.M. Baker, Condorcet: From Natural Philosophy to Social Mathematics, University of Chicago Press, Chicago 1975.

${ }^{11}$ S. Charles, Introduction: What is Enlightenment Scepticism? A Critical Rereading of Richard Popkin, in S. Charles, P.J. Smith (eds), Scepticism in the Eighteenth Century..., p. 12. 
At the beginning of the eighteenth century, scepticism was still a living philosophical current. Two philosophers who made the most significant contribution to the sceptical tradition of that time were Pierre Bayle and Pierre Daniel Huet. In his Critical and Historical Dictionary, Bayle used sceptical arguments to undermine reason and turn to faith instead. The incompetent reason has nothing to say in matters of religious faith since the truth of Christianity is guaranteed by the "supreme authority of God." 12 Scepticism in its Pyrrhonian version is not only harmless to religion, but also opens the road to fideism. Huet contributed to classical scepticism. He also considered scepticism a good introduction to theology, but his main contribution involved theoretical arguments justifying the key theses of scepticism.

David Hume seems to be the only great philosopher of the Enlightenment who declared himself a sceptic. However, Hume's scepticism is far from unambiguous, as evidenced by disputes that began during his lifetime and have continued to this day. It is indisputable that Hume was influenced by Bayle. Hume considered various types of scepticism in his work, including radical (Pyrrhonian), mitigated, Cartesian and religious scepticism. According to him, human beliefs have no foundation in reason and senses, but they are based on instinct and custom. Such scepticism concerning human knowledge is clearly visible in Hume's critique of basic categories of the classical metaphysics as well as religious belief. In his scepticism, Hume does not go as far as Pyrrhonian philosophers. The destructive theoretical scepticism presented in A Treatise on Human Nature is unacceptable in practical life. What Hume called natural belief is indispensable in everyday life because one has no alternative to such belief. In other words, one needs to accept certain beliefs in their lives even if they cannot be justified through reason or experience. Therefore, Hume proposed a form of "mitigated scepticism or academical philosophy, which may be both durable and useful, and which may, in part, be the result of this Pyrrhonism, or excessive scepticism, when its undistinguished doubts are, in some measure, corrected by common sense and reflection." ${ }^{13}$ He also suggests another form of mitigated scepticism, which consists in choosing such an object of inquiry that it lies within our cognitive abilities. In Hume's moderate scepticism, the suspension of judgement is not always possible in everyday life and one has to respect some common-sense beliefs, as one is inclined by nature to do so. Yet it does not mean that common-sense beliefs become thus justified. On the contrary, Hume constantly emphasized that those beliefs remain unfounded. The value of such an approach lies in its ability to free the human from illusions and dogmatic attitudes.

Hume's scepticism had a huge impact on Kant's critical philosophy. Kant himself admitted that Hume's philosophy had had a decisive influence on his philosophical studies. In Prolegomena, he states as follows: "I freely admit that

12 P. Bayle, Historical and Critical Dictionary, Bobbs-Merrill, Indianapolis 1965, p. 421.

13 D. Hume, An Enquiry Concerning Human Understanding, Oxford University Press, Oxford 2007, p. 117. 
the remembrance of David Hume was the very thing that many years ago first interrupted my dogmatic slumber and gave a completely different direction to my researches in the field of speculative philosophy." ${ }^{14}$ Like Hume, Kant criticized the dogmatism of speculative philosophy, but he was unwilling to follow the path of scepticism. Kant's own solution was a middle ground between excessive scepticism and dogmatism. No matter how precisely one interprets Kant's attitude to scepticism, the fact remains that scepticism determined the direction of his philosophy.

The influence of scepticism on Enlightenment philosophy was particularly visible in the criticism of religion, i.e. the explanation of religious phenomena in terms of reasons and causes that can be rationally controlled. Such criticism is an important part of Hume's philosophy, and cannot be discussed in separately from Hume's mitigated scepticism. It was Hume's criticism of religion which, along with his historical works, had impact on French philosophers such as Voltaire, Helvetius, and Holbach. Although the latter ignored Hume's epistemological scepticism, they greatly admired his criticism of religion which was undoubtedly based on his scepticism. According to Hume's mitigated scepticism, one's fundamental beliefs can be justified neither by reason nor by experience. They are based on instinct, habit and imagination. The inability to prove those beliefs does not mean that they should be rejected. This is especially true of the so-called natural beliefs (for instance, in everyday life, one cannot constantly reject a belief in the existence of the external world). Natural beliefs are a result of psychological mechanisms. Since they are not based in reason, they are immune to sceptical criticism. The question whether religious beliefs are natural beliefs is a matter of ongoing debate. Their origin lies in human nature and they do not need to be justified in order to emerge in human mind. What makes them different from natural beliefs is that according to Hume they are not protected from sceptical doubt. Consequently, it would seem that fundamental religious beliefs — such as a belief in the existence of God—can be criticized in a more radical manner because they are not as indispensable in everyday life as some natural beliefs, e.g. a belief in the existence of the external world.

Hume's philosophy of religion is not the only example of scepticism being employed in the critique of religion. Many other philosophers, especially in France, were inclined to use scepticism to assail some forms of religion. The alliance between scepticism and criticism of religion was noticed by those thinkers for whom scepticism posed a threat to the Christian tradition. According to Popkin, "in the $18^{\text {th }}$ century scepticism [...] began to be seen also as a principal weapon against religious belief. The term "sceptic" no longer meant just a doubter about various claims to knowledge about an external reality, but came to have as a major meaning, a doubter in the Judeo-Christian tradition." ${ }^{15}$ It must be remembered, however, that

${ }^{14}$ I. Kant, Prolegomena to Any Future Metaphysics, Cambridge University Press, Cambridge 1997, p. 10.

15 R.H. Popkin, New Views on the Role of Scepticism in the Enlightenment, in R.H. Popkin et al. (eds), Scepticism in the Enlightenment, p. 158. 
this was by no means the only possible understanding of scepticism, which had in fact been an ally of fideism for centuries. As already noted, sceptical fideism was still alive at the beginning of the eighteenth century.

The reception of Hume's works among French intellectuals of the eighteenth century eloquently demonstrates that scepticism attracted little interest in France. The French intellectual world was much more interested in the historical and political works of Hume's than in his scepticism. While Hume's History of England was widely read and admired in France, his Treatise of Human Nature was not so much rejected and criticized as simply ignored. Even those philosophers who appreciated Hume's criticism of religion and his moral writings, ignored his epistemological scepticism. For instance, Voltaire found scepticism a destructive and self-destructive philosophy which could not be taken seriously by any sane and reasonable man. ${ }^{16}$ Still, even if the Enlightenment criticism of religion was not, except Hume, based on epistemological scepticism, it nevertheless drew from Hume's works on religion, which for their part had been strongly influenced by the sceptical tradition.

The role of scepticism in the philosophy of the Enlightenment requires further studies. We know much about the self-declared sceptics of the eighteenth-century philosophy. At the same time, we have little knowledge of the role of scepticism in the works of the philosophers who were not sceptics but were under the influence of scepticism. As S. Charles and P.J. Smith observe, "the precise function of Enlightenment scepticism remains for the most part terra incognita." ${ }^{17}$ Insufficient knowledge about the role of scepticism in the eighteenth century seems to be the main reason why the Enlightenment has been treated as a hiatus in the history of scepticism.

\section{Literature}

Baker K.M., Condorcet: From Natural Philosophy to Social Mathematics, University of Chicago Press, Chicago 1975.

Bayle P., Historical and Critical Dictionary, Bobbs-Merrill, Indianapolis 1965.

Charles S., Smith P.J. (eds), Scepticism in the Eighteenth Century: Enlightenment, Lumières, Aufklärung, Springer, Dordrecht 2013.

Drozdowicz Z., Faces of the Enlightenment, Peter Lang, Berlin 2020.

Hume D., An Enquiry Concerning Human Understanding, Oxford University Press, Oxford 2007.

Kant I., Prolegomena to Any Future Metaphysics, Cambridge University Press, Cambridge 1997.

Paganini G. (ed.), The Return of Scepticism, Kluwer Academic, Dordrecht 2003.

${ }^{16}$ Ibidem, p. 9.

17 S. Charles, P.J. Smith, Preface, in S. Charles, P.J. Smith (eds), Scepticism in the Eighteenth Century..., p. xi. 
Popkin R., The History of Scepticism: From Savonarola to Bayle, Oxford University Press, Oxford 2003.

Popkin R.H., Vanderjagt (eds), Scepticism and Irreligion in the Seventeenth and Eighteenth Centuries, Brill, Leiden 1993.

Popkin R.H. et al. (eds), Scepticism in the Enlightenment, Kluwer Academic, Dordrecht 1997.

Reed B., Machuca D.E., Skepticism: From antiquity to the present, Bloomsbury, London 2018. 